\title{
Wettability, Shrinkage and Color Changes of Araucaria angustifolia After Heating Treatment
}

\author{
Rodrigo Marques de Oliveira, André Brisolari, Almir Sales ${ }^{\mathrm{b}}$, Débora Gonçalves ${ }^{\mathrm{a},}$ \\ ${ }^{a}$ Instituto de Física de São Carlos, Universidade de São Paulo - USP, \\ Av. Trabalhador São-carlense 400, CP 369, CEP 13560-970, São Carlos, SP, Brazil \\ ${ }^{\mathrm{b}}$ Departamento de Engenharia Civil, Universidade Federal de São Carlos - UFSCar, \\ CP 676, CEP 13565-905, São Carlos, SP, Brazil
}

Received: February 25, 2010; Revised: June 22, 2010

\begin{abstract}
The effects of thermal treatment on the wettability and shrink resistance of Araucaria angustifolia (Parana pine) were studied from 20 to $200{ }^{\circ} \mathrm{C}$. The contact angles of water droplets on untreated and heat-treated samples were measured by the sessile drop method in the grain of heartwood and sapwood cut in the radial, longitudinal, and tangential directions. A significant increase of the contact angles was verified for the samples from room temperature to $120{ }^{\circ} \mathrm{C}$, in particular in the radial and tangential directions; at higher temperatures, the contact angles assumed almost constant values. From 120 to $200{ }^{\circ} \mathrm{C}$, the sapwood of Araucaria angustifolia showed better dimensional stability and lower thermal resistance when compared to the heartwood. Variations of color were also studied by using the CIELab system, which showed to be capable of accurately distinguishing samples treated at different temperatures.
\end{abstract}

Keywords: Araucaria angustifolia, wettability, wood, contact angles, surface modifications

\section{Introduction}

The environmental impact caused by biocides and preservatives, as well as by cumulative disposal of treated and waste woods, is one of the reasons why researchers around the world have been investigating alternative methods of wood management and preservation ${ }^{1,2}$. One of these approaches is to study how the thermal treatment used in the wood manufacturing industry affects some of the natural characteristics of woods, including durability, shape stability, and discoloration, which are mainly caused by loss of extractives and/or effects of chemical degradation.

Understand the surface modification of wood that takes place by heating is extremely important, in particular for industrial application, since properties such as surface quality, dimensional stability and/ or anisotropy factor may change drastically ${ }^{3}$. The temperature induces various changes in the surface of wood, thus decreasing its hydrophilic characteristics and, consequently, wettability, an important characteristic to be evaluated when water-based color coatings are intended to be used to protect and recover surfaces ${ }^{4}$. Furthermore, after heating the wood becomes to exhibit different retraction or expansion ratios along the growth directions (anisotropy), and also, swelling and shrinkage effects, which are not usually verified on untreated woods.

Previous studies have revealed that the resistance of different species of wood to attacks by termites and rot fungi is higher when they are heat-treated, and this enhancement of the biological resistance is partially explained by low equilibrium moisture contents ${ }^{5}$. Temperatures below $200{ }^{\circ} \mathrm{C}$ allows one to avoid effects of wood destruction, once decomposition of wood usually takes place at $225-325{ }^{\circ} \mathrm{C}$ as verified by color changes, loosening of wood fibers, dimensional changes, and surface cracks ${ }^{6-8}$. It is well known that mild pyrolysis has been also used for assuring wood a large dimensional stability and better durability; however, removal of extractives and destruction of important polysaccharides (partial or total), such as hemicellulose and lignin, take place at high temperatures and are verified in the curves of mass loss for different species of $\operatorname{wood}^{5,9,10}$.

Our contribution here was to evaluate the effects of heating on the wettability and shrinkage of Araucaria angustifolia (Parana pine) from ambient to $200{ }^{\circ} \mathrm{C}$, a temperature range that is out of the zone of thermal decomposition of wood. Araucaria angustifolia is a native wood variety with favorable properties, such as a soft yellow color, softness, low density, low retraction, and extremely useful for application in furniture and construction finish materials.

Today is a sad reality the huge areas of wood forests have been devastated; within this context, reforestation becomes a priority to practicing sustainable forestry. A lot of research must be still carried out to characterize several species of woods, and to the best of our knowledge, there are no studies on effects of high temperatures on the surface properties of native forest species such as Araucaria angustifolia.

\section{Experimental Procedure}

Araucaria angustifolia (Parana pine) samples were cut into $2 \times 3 \times 5 \mathrm{~cm}$ pieces in the tangential, radial, and longitudinal directions from the same board ${ }^{11}$. The wood samples were previously dried up at $103 \pm 2{ }^{\circ} \mathrm{C}$ in an oven in order to obtain stable values of mass (anhydrous mass), usually after about 48 hours. The dry samples were then heated at different temperatures from ambient to operating temperatures of $120,140,160,180$ and $200{ }^{\circ} \mathrm{C}$ in an oven at $5^{\circ} \mathrm{C} / \mathrm{min}$ for 8 hours. After the thermal treatment, the temperature decreased automatically from the operating temperature to $22{ }^{\circ} \mathrm{C}$, when the contact angles were measured for a set of at least 20 heat-treated samples at a relative humidity level of about $45-55 \%$.

The contact angles were measured by the sessile drop method using a home-build goniometer. For each sample, five drops of $5 \mu \mathrm{L}$ 
of distilled water were deposited on the wood surface at different locations; after that, the contact angles were measured in the radial, longitudinal, and tangential directions of the wood samples. At least ten measurements were made in order to avoid interferences on the values of contact angles due to structural and chemical variations of the wood samples. The contact angles were measured about 5 seconds after depositing the water drop on the wood surface because this period of time is necessary in order to obtain droplet stabilization and avoid effects of solvent contamination with wood extractives ${ }^{12}$. All image sets were analyzed with computer software, ImageJ software.

The same samples used for the contact angle measurements had their color changes monitored using a surface reflectance spectrophotometer PocketSpec Technologies. The color was calculated from the CIEL*a*b*3D system ${ }^{13}$, in which the coordinates $\mathrm{a}^{*}$ indicate a variation from red $(+)$ to green $(-), \mathrm{b}^{*}$, from yellow $(+)$ to blue (-), and $\mathrm{L}^{*}$, white (100) to black (0).

\section{Results and Discussion}

Initially, we studied how the contact angles varied for sapwood and heartwood of Araucaria angustifolia at different growth directions from 20 to $200{ }^{\circ} \mathrm{C}$, and these results are shown in Figure 1. The contact angles were also monitored with time for the samples heated at $180{ }^{\circ} \mathrm{C}$.

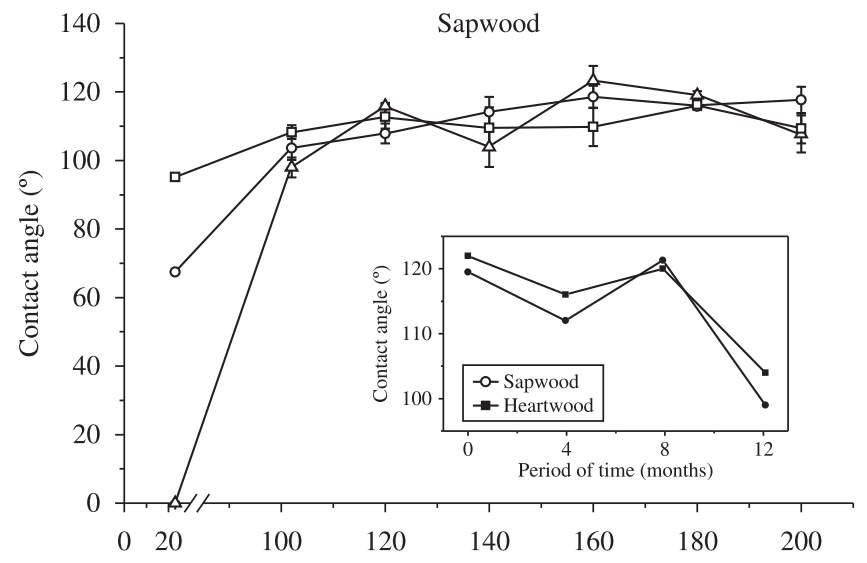

(a)

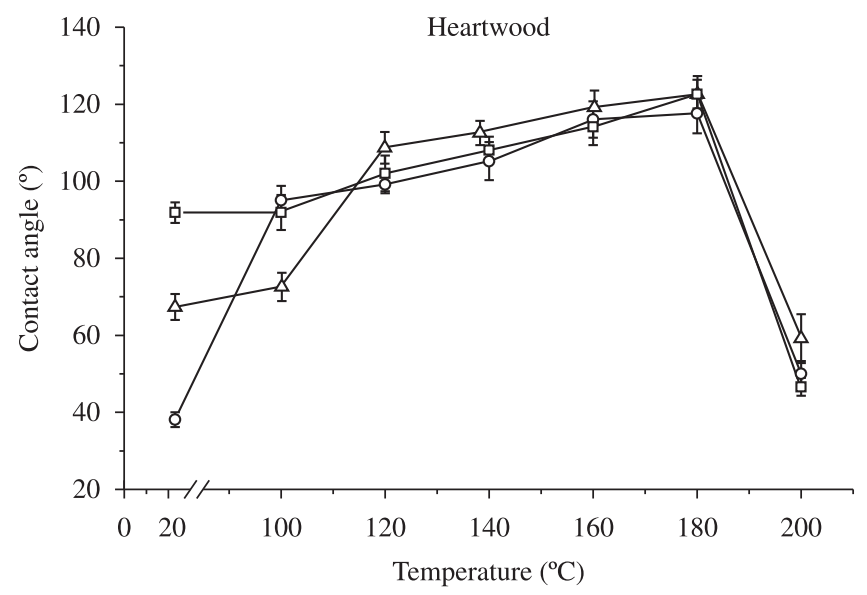

(b)

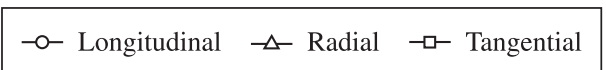

Figure 1. Contact angles measured after the heating treatment for Araucaria angustifolia at different growth directions: a) sapwood; and b) heartwood.
For Araucaria angustifolia there is a clear difference in the contact angles at $20{ }^{\circ} \mathrm{C}$, in particular for sapwood (Figure 1a). For example, the contact angle increases from near zero, a condition of great wettability/high hydrophilicity, to about $108^{\circ}$ in the radial direction. In the tangential direction, the variation of contact angle is not so evident, from about $95^{\circ}$ at $20^{\circ} \mathrm{C}$ to $108^{\circ}$ at $100{ }^{\circ} \mathrm{C}$. From 120 to $180{ }^{\circ} \mathrm{C}$, the contact angle assumes practically constant values, at about $115^{\circ}$, for both sapwood and heartwood, but from 160 to $180^{\circ} \mathrm{C}$, the contact angle decreases from $115^{\circ}$ to its original value for heartwood (Figure 1b). In this case, the samples become to exhibit drying defects (cracks, fissures or wrinkles) after $180{ }^{\circ} \mathrm{C}$ due to effects of absorption of water and an enhanced wettability of the wood surface. For sapwood, there is no clear evidence of drying defects because sapwood is moister than heartwood, thus absorbing more efficiently heat and keeping protected its inner structures.

At first sight, we related the high hydrophobicity of heat-treated Araucaria angustifolia to an effect of migration of volatile extractives from the inner walls to surface of the wood samples. However, similar results than those seen in Figure 1 were obtained after removal of volatile extractives from the wood samples. In this case, the wood extractives were removed from the samples according to a procedure described in the literature ${ }^{14}$. Besides, since the contact angles vary considerably at temperatures below $100^{\circ} \mathrm{C}$, migration and vaporization of extractives from the wood surface cannot be related to differences in the contact angles after increasing temperature. Therefore, we infer that the large variation of wettability of Araucaria angustifolia is due to conformational variations of the cellulose molecules, and also, plasticizing effects of lignin at certain water content, as it was previously reported for other wood species ${ }^{15-18}$.

Generally speaking, the contact angle is constant for sapwood of Araucaria angustifolia from 160 to $200{ }^{\circ} \mathrm{C}$ due to a higher hydrophobic condition of the wood sample; for heartwood, the contact angle decreases drastically at $200{ }^{\circ} \mathrm{C}$, thus evidencing that the sample recovers its hydrophilic nature. However, these differences are not so evident for measurements of mass loss after varying temperature.

A considerable percentage of mass loss was verified for Araucaria angustifolia after heating according to calculations from Equation 1, where $m_{i}$ is the initial mass of dried sample before heating treatment, and $m_{h}$ is the mass of the same sample, but after heating treatment:

$$
\Delta m(\%)=100 x \frac{\left(m_{i}-m_{h}\right)}{m_{h}}
$$

Figure 2 shows the percentage of mass loss for heartwood and sapwood of Araucaria angustifolia from 120 to $200{ }^{\circ} \mathrm{C}$. Below $160{ }^{\circ} \mathrm{C}$, the mass loss is not significantly high, and it can be mainly attributed to a thermal loss of water, triglycerides and waxes. After this temperature, the samples lose very fast a certain percentage of mass (about $8 \%$ at $200{ }^{\circ} \mathrm{C}$ ), particularly for heartwood. These results can be explicated not only due to the elimination of volatile extractives, but also, to structural water that is pulled out of the surface of wood at higher temperatures $\left(200{ }^{\circ} \mathrm{C}\right.$ or over). In this case, the temperature is high enough to degrade hemicelluloses and then, reduce the presence of $\mathrm{OH}$ groups in the wood cell walls ${ }^{19,20}$. Furthermore, vaporization of larger extractive molecules (such as fatty acid esters) takes place at temperatures higher than $150{ }^{\circ} \mathrm{C}$, mainly for heartwood, where the concentration of those molecules is comparatively high ${ }^{21}$. In the literature, a mass loss of $30 \%$ was obtained for Grevillea robusta at $250{ }^{\circ} \mathrm{C}$, and therein loss of volatile products was related to degradation of hemicelluloses and extractives ${ }^{22}$. When the wood samples are treated at temperatures below $100{ }^{\circ} \mathrm{C}$, the loss of organic material is not significantly high, and any mass variation seen for this case can be only attributed to a loss of adsorbed water from the wood surface ${ }^{23}$. 


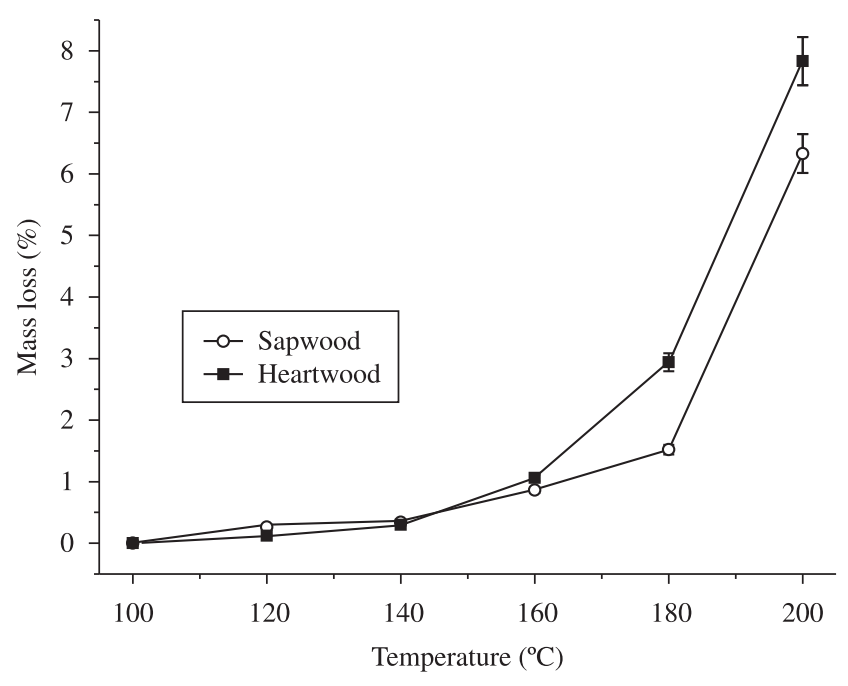

Figure 2. Mass loss with temperature for Araucaria angustifolia (sapwood and heartwood).

The dimensional variations of Araucaria angustifolia after heating were also measured by using a commercial, electronic digital dial caliper (Figure 3). Both heartwood and sapwood exhibited higher dimensional variations after increasing temperature, in particular in the tangential direction, since wood deformation is expected at high temperatures. The literature describes that the dimensional variation in the tangential direction for several species of woods is usually twice than that observed in the radial direction ${ }^{24}$.

For sapwood of Araucaria angustifolia, an interesting result, which can be noticed in Figure 3, is an anisotropy factor equals to 1 at $140{ }^{\circ} \mathrm{C}$, allowing us to assure a good dimensional stability at this temperature. On the other hand, heartwood is a consolidated-type tissue with meaningful amounts of extractives and other organoleptic compounds; these characteristics explain a higher size deformation seen for samples treated at higher temperatures $\left(>160{ }^{\circ} \mathrm{C}\right)$, and which may exhibit cracks, mainly in the capillary structures.

The color variations of the heat-treated samples were also obtained according to the CIEL*a*b* system, a methodology that has been used to characterize the color variations for different species of woods e.g. after preservative treatments ${ }^{23}$ and artificial UV light exposures ${ }^{10}$. We obtained the values of $L^{*}, a^{*}, b^{*}$, and from these data, calculated the values of $\Delta \mathrm{E}$ according to Equation 2:

$$
\Delta E=\sqrt{\Delta L^{* 2}+\Delta a *^{2}+\Delta c^{* 2}}
$$

which describes the overall color changes of the samples in relation to the same measurements for samples at room temperature.

Figure 4 shows the $\Delta \mathrm{E}$ values with the heating treatment for Araucaria angustifolia (sapwood and heartwood). As it can be seen in Figure 4, the color does not vary significantly below $160{ }^{\circ} \mathrm{C}$; but after that, the samples become darker, in particular for the sapwood, thus indicating that the color varies earlier from the surface to the inner part of the wood sample.

The change in color for Araucaria angustifolia also showed to be less evident for heartwood, thus indicating that this wood region is more resistant to effects of heating than the sapwood once it contains more extractives in its channels. The presence of these volatile extractives may have contributed to better dissipate heat, thus reducing the thermal conductivity of wood. Sapwood, on the other hand, undergoes faster degradation caused by heating. Similar
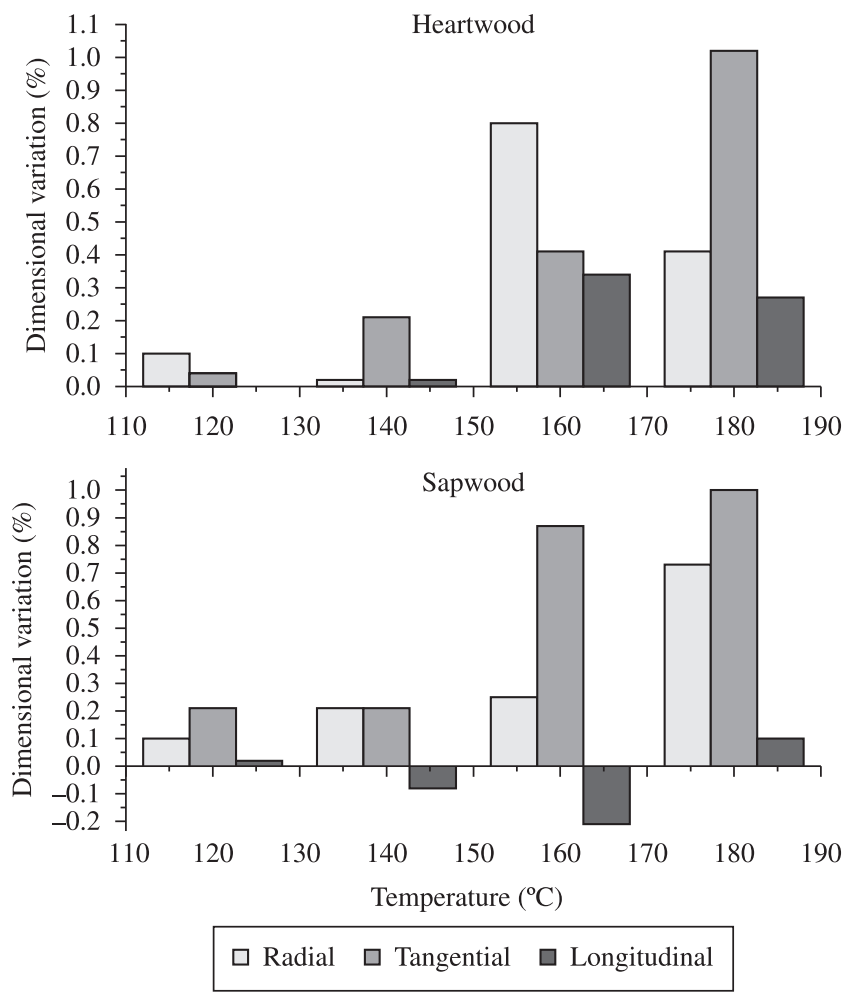

Figure 3. Dimensional variation with temperature for Araucaria angustifolia (sapwood and heartwood) at different growth directions.

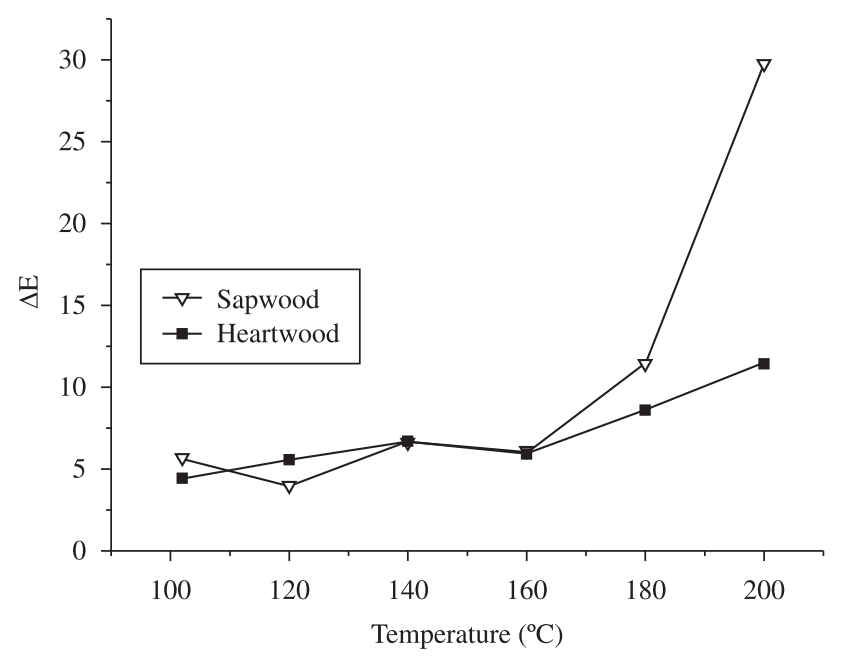

Figure 4. Color changes $(\Delta \mathrm{E})$ for Araucaria angustifolia under different temperature treatments.

results of $\Delta \mathrm{E} v s$ temperature were also obtained in the literature for softwoods (Pine and Alder) treated with preservatives ${ }^{25}$, and one of the effects that contributed most for the darkening of the wood is a partial degradation of extractives under heating. This mechanism, however, has not been clearly discussed in the literature, since it is based on complex reactions involving by-products and other wood constituents, and may involve degradation of lignins followed by reactions of chromophores, which yields a yellowish color and, subsequently, effects of darkening of the wood ${ }^{26}$. 


\section{Conclusions}

The thermal treatment of Araucaria angustifolia between 120 and $200{ }^{\circ} \mathrm{C}$ decreases significantly its surface hydrophilicity even without verifying a considerable effect of mass loss. The stabilization of the contact angles for heat-treated samples was verified for temperatures higher than $150{ }^{\circ} \mathrm{C}$. Heartwood of Araucaria angustifolia showed to be not resistant to temperatures higher than $180{ }^{\circ} \mathrm{C}$, since after this temperature, the samples become to exhibit fissures and warping. Furthermore, the dimensional stability of the wood samples showed to be worse after thermal treatments; an expected behavior for shrinkage was verified from room temperature to $120{ }^{\circ} \mathrm{C}$, and heartwood of Araucaria angustifolia showed to be less heat resistant than sapwood. All these measurements are cheap and fast for characterizing surfaces when all equipments and samples are promptly available; this gain of time could optimize procedures for reception and control of woods in the industries. The CIELab system allowed us to conclude that no color difference can be noticed for heartwood and sapwood of Araucaria angustifolia below $160{ }^{\circ} \mathrm{C}$. The samples become darker after heating above $160^{\circ} \mathrm{C}$, since chemical degradation takes place under high temperatures.

\section{Acknowledgements}

The authors acknowledge support by FAPESP, CAPES and MCT/ CNPq, and Prof. F.A. Durao for suggestions and language assistance.

\section{References}

1. Barnes HM and Murphy RJ. Wood preservation: the classics and the new age. Forest Products Journal. 1995; 45:16-23.

2. Brand MA, Anzaldo J and Moreschi JC. Novos produtos para o tratamento preservante da madeira: Perspectivas da pesquisa e utilização. Floresta. 2006; 36:129-137.

3. Panshin AJ and De Zeeuw C. Textbook of wood technology. New York: McGraw-Hill; 1980.

4. Back E. Oxidative activation of wood surfaces for glue bonding. Forest Products Journal. 1991; 41:30-36.

5. Hakkou M, Pétrissans M, Gérardin P and Zoulalian A. Investigations of the reasons for fungal durability of heat-treated beech wood. Polymer Degradation and Stability. 2006; 91:393-397.

6. Futo LP. Effects of temperature on the photochemical degradation of wood, I. Experimental presentations. Holz als Roh-und Werkstoff. 1976; 34:31-36.

7. Shafizadeh F and Fu YL. The chemistry of pyrolysis and combustion. Rowell RM, editor. The Chemistry of Solid Wood. Washington: DC American Chemical Society; 1984. p. 489-529.

8. Willians RS and Feist WC. Wood modified by inorganic salts: mechanism and properties: I. Weathering rate, water repellency, and dimensional stability of wood modified with chromium (III) nitrate versus chromic acid. Wood Fiber Science. 1985; 17:184-198.

9. Vovelle $\mathrm{C}$ and Mellottee H. Modelisation de la pyrolise oxydante ou nonoxydante de bois ou de déchéts végetaux à partir de leurs composants. In:
Pals W and Chartier P, editors. Energy from biomass. London: Applied Sciences; 1982. p. 925-929.

10. Kamdem DP, Pizzi A and Jermannaud A. Durability of heat-treated wood. Holz als Roh-und Werkstoff. 2002; 60:1-6.

11. British Standards Institution. Nomenclature of commercial timbers including sources of supply. BS 7359. BSI, 1991.

12. Walinder MEP and Johansson I. Measurement of wood wettability by the Willhelmy method. Part 1. Contamination of probe liquids by extractives. Holzforschung. 2001; 55:21-32.

13. Billmeyer Jr FW. Principles of Color Technology. $3^{\text {th }}$ ed. New York: Wiley-Interscience; 2000. 304 p.

14. Tappi standard. Solvents extractives for wood and pulp. T 204 om-88. TAPPI; 1987.

15. Alén R, Kotilainen R and Zaman A. Thermochemical behavior of Norway spruce (Picea abis) at $180-225^{\circ} \mathrm{C}$. Wood Science and Technology. 2002; 36:163-171.

16. Pétrissans M, Gérardin P, El Bakali I and Serraj M. Wettability of heattreated wood. Holzforschung. 2003; 57:301-307.

17. Wiland JJ and Guyonnet R. Study of chemical modifications and fungi degradation of thermally modified wood using DRIFT spectroscopy. Holz als Roh-und Werkstoff. 2003; 61:216-20.

18. Mburu F, Dumarçay S, Bocquet JF, Petrissans M and Gérardin P. Effect of chemical modifications caused by heat treatment on mechanical properties of Grevillea robusta wood. Polymer Degradation and Stability. 2008; 93:401-405.

19. Figueroa MJM and de Moraes PD. Comportamento da madeira a temperaturas elevadas. Ambiente Construído. 2009; 09(04):157-174.

20. Kocaefe D, Poncsak S, Doré G and Younsi R. Effect of heat treatment on the wettability of white ash and soft maple by water. Holz Roh Werkst. 2008; 66:355-361.

21. Hakkou M, Pétrisans M, Zoulalian A and Gérardin P. Investigation of wood wettability changes during heat treatment on the basis of chemical analysis. Polymer Degradation and Stability. 2005; 89:1-5.

22. Mburu F, Dumarçay S, Huber F, Petrissans M and Gérardim P. Evaluation of thermally modified Grevillea robusta heartwood as an alternative to shortage of wood resource in Kenya: Characterization of physicochemical properties and improvement of bio-resistance. Bioresource Technology. 2007; 98:3478-3486.

23. Brito JO, Garcia JN, Bortoletto Júnior G, Pessoa AMC and Silva PHM. Densidade básica e retratibildade da madeira de Eucalyptus grandis submetida a diferentes temperaturas de termorretificação. Cerne. 2006; 12:182-188.

24. USDA. Forest Service Wood Handbook: Wood as an Engineering Material. Madison: USDA Agriculture Handbook 72; 1999.

25. Temiz A, Yildiz UC, Aydin I, Eikenes M, Alfredsen G and Çolakoglu G. Surface roughness and color characteristics of wood treated with preservatives after accelerated weathering test. Applied Surface Science. $2005 ; 250: 35-42$.

26. George B, Sutie E, Merlin A and Deglise X. Photodegradation and photostabilisation of wood - the state of the art. Polymer Degradation and Stability. 2005; 88:268-274. 